\title{
ODMOWA WSZCZECIA POSTĘPOWANIA ADMINISTRACYJNEGO W KONTEKŚCIE ART. 61A KODEKSU POSTĘPOWANIA ADMINISTRACYJNEGO
}

\section{WPROWADZENIE}

W dniu 11 kwietnia 2011 r. weszła w życie obszerna nowelizacja Kodeksu postępowania administracyjnego ${ }^{1}$. Zmiany zostały wprowadzone na mocy ustawy z 3 grudnia 2010 r. o zmianie ustawy - Kodeks postępowania administracyjnego oraz ustawy - Prawo o postępowaniu przed sądami administracyjnymi (Dz. U. 2011, Nr 6, poz. 18). Jedna ze zmian polegała na dodaniu po art. 61 przepisu art. 61a. Reguluje on problem, który w nauce prawa oraz w orzecznictwie sądów administracyjnych określany jest jako odmowa wszczęcia postępowania.

Znaczenie powyższej zmiany od razu zostało docenione w literaturze przedmiotu, gdzie określono ją jako ,jedna z najważniejszych zmian” a nawet jako: ,zmianę nie do przecenienia” spośród wszystkich zmian wprowadzonych do kodeksu w 2011 r. $^{2}$

Wprowadzenie tego przepisu było od dawna oczekiwane. Dotychczasowe unormowanie k.p.a., poza wyjątkowymi przypadkami ujętymi w art. $31 \S 2$ (przewidującym wydanie postanowienia o wszczęciu postępowania na skutek żądania organizacji społecznej) ${ }^{3}$, art. $149 \S 1$ (nakazującym wydanie postanowienia w sprawie wszczęcia wznowionego postępowania), art. $31 \S 2$ (dopuszczającym wydanie postanowienia o odmowie wszczęcia postępowania na żądanie organizacji społecznej) oraz art. $149 \S 3$ (o odmowie wszczęcia postępowania w sprawie wznowienia postępowania) oraz art. $157 \S 3$ (o odmowie wszczęcia postępowania w sprawie stwierdzenia nieważności decyzji), nie regulowało formy wszczęcia postępowania administracyjnego, a zwłaszcza formy odmowy jego wszczęcia.

Pod rządami rozporządzenia z moca ustawy z 22 marca 1928 r. o postępowaniu administracyjnym (Dz. U. R. P. Nr 36, poz. 341; dalej: r.p.a.), zagadnienie

${ }^{1}$ Dalej: k.p.a. bądź Kodeks; artykuły przywoływane w niniejszym opracowaniu bez bliższego określenia oznaczają przepisy tej ustawy.

${ }^{2}$ W. Chróścielewski, Zmiany w zakresie przepisów kodeksu postępowania administracyjnego i prawa o postepowaniu przed sadami administracyjnymi, które weszty w życie w 2011 r., ,Zeszyty NSA” 2011, nr 4, s. 14 .

${ }^{3}$ Wyrok NSA z 15 lipca 1992 r., V SA 178/92, ONSA 1993, nr 1, poz. 20. 
to rozpatrywano w kontekście art. 71 r.p.a., który stanowił: „Jeżeli nie ma podstawy prawnej lub faktycznej do merytorycznego załatwienia sprawy będącej przedmiotem podania, władza pozostawia je bez załatwienia, a sprawę wszczętą już umarza, czyniąc odpowiednią adnotację na akcie i $\mathrm{w}$ miarę okoliczności zawiadamiając petenta". Powyższe rozwiązanie r.p.a. budziło jednak dyskusje oraz przyczyniło się do istotnej polaryzacji poglądów ${ }^{4}$.

Pod rządami k.p.a. sprawa wszczęcia oraz odmowy wszczęcia postępowania również stanowiła przedmiot rozważań $\mathrm{w}$ nauce prawa oraz $\mathrm{w}$ orzecznictwie sądowoadministracyjnym. W doktrynie przeważał pogląd, że k.p.a. nie znał i nie zna osobnego aktu wszczęcia postępowania administracyjnego ${ }^{5}$.

Zagadnienie formy wszczęcia jurysdykcyjnego postępowania administracyjnego, a zwłaszcza odmowy wszczęcia takiego postępowania, jest niezwykle istotne dla podmiotu administrowanego. Wydanie przez organ administracji publicznej aktu w przedmiocie wszczęcia postępowania administracyjnego umożliwia podmiotowi administrowanemu poddaniu tego aktu weryfikacji poprzez uruchomienie środków prawnych ${ }^{6}$. Tym bardziej że nie każde pismo, zawierające wniosek czy żądanie, skierowane do organu administracji publicznej może (i powinno) spowodować wszczęcie postępowania administracyjnego. Zwrócił na to uwagę NSA w wyroku z 26 lutego 1992 r., w którym skonstatował, że: ,żądanie o charakterze cywilnoprawnym, skierowane do organu administracji rządowej lub samorządowej, nie wszczyna postępowania na podstawie art. $61 \S 3 \mathrm{Kpa"}$.

\section{DO WEJŚCIA W ŻYCIE NOWELIZACJI K.P.A.}

Do 11 kwietnia 2011 r. (czyli do dnia wejścia w życie nowelizacji k.p.a.) powszechnie akceptowano pogląd, według którego postępowanie administracyjne wszczyna organ administracji publicznej $\mathrm{w}$ sprawie indywidualnej, załatwianej $\mathrm{w}$ formie decyzji administracyjnej $\mathrm{z}$ własnej inicjatywy lub na żądanie jednostki, która według własnej oceny ma w danej sprawie interes prawny ${ }^{8} . \mathrm{Z}$ rozwiązań przyjętych w art. $61 \S 1 \mathrm{i}$ art. $61 \S 3$ wynikało, iż przepisy k.p.a. nie przewidywały wydania przez organy administracji publicznej odrębnego rozstrzygnięcia w formie decyzji lub postanowienia. Spełnienie warunków co do strony przedmiotowej i podmiotowej postępowania rodziło obowiązek podjęcia czynności przez organ administracji publicznej. J. Starościak prezentował pogląd, że ,zawiadomienie o odmowie wszczęcia postępowania, pomimo

\footnotetext{
${ }^{4}$ Szerzej na ten temat B. Adamiak, w: eadem, J. Borkowski, Kodeks postepowania administracyjnego. Komentarz, wyd. 11, Warszawa 2011, s. 293-294, nb. 1.

${ }^{5}$ E. Iserzon, J. Starościak, Kodeks postępowania administracyjnego. Komentarz, teksty, wzory $i$ formularze, wyd. 4, Warszawa 1970, s. 144; W. Dawidowicz, Ogólne postępowanie administracyjne. Zarys systemu, Warszawa 1962, s. 126; Z. Janowicz, Kodeks postepowania administracyjnego. Komentarz, wydanie 2, Warszawa 1995, s. 167; B. Adamiak, w: eadem, J. Borkowski, Polskie postepowanie administracyjne, wyd. 4, Warszawa 1999, s. 135.

${ }^{6}$ B. Adamiak, op. cit., s. 294.

7 Teza wyroku z glosą Z. Janowicza, „Przegląd Sądowy” 1995, nr 4, s. 92.

${ }^{8}$ Z. Janowicz, Postepowanie administracyjne $i$ postepowanie przed sadem administracyjnym, Warszawa-Poznań 1982, s. 152.
} 
złożenia przez stronę wniosku o jego wszczęcie, jest decyzją, od której przysługuje odwołanie" 9 . Powyższe stanowisko znalazło swoje odzwierciedlenie w orzecznictwie sądowoadministracyjnym. Jak stwierdził NSA w wyroku z 18 stycznia 1989 r. (III SA 903/88):,,[...] organ administracji nie może odmówić wszczęcia postępowania na wniosek strony, mimo oceny, że żądanie strony jest bezzasadne $\mathrm{z}$ przyczyn formalnych, czy merytorycznych" ${ }^{10}$. Oznaczało to, iż nawet w przypadkach, w których do wydania merytorycznego rozstrzygnięcia nie powinno dojść na przykład z tego powodu, że rozstrzygnięcia tego żądała osoba nielegitymowana, a więc niemająca w danej sprawie interesu prawnego, lub droga administracyjna była niedopuszczalna), konieczne było podjęcie czynności postępowania oraz zamknięcie tego postępowania decyzją: merytoryczną (rozstrzygającą sprawę żądania) ${ }^{11}$ albo procesową (umarzająca wszczęte postępowanie administracyjne ze względów przedmiotowych lub podmiotowych $)^{12}$.

Rozwiązanie z art. 61a k.p.a. wypełniło istotną lukę w systemie postępowania administracyjnego. Jak już wcześniej wspomniano, Kodeks nie określał formy odmowy wszczęcia postępowania. W dorobku judykatury utrwalił się pogląd, obarczony błędem logicznym (na który od dawna zwracał uwagę W. Chróścielewski ${ }^{13}$ ), iż ,„»żądanie o charakterze cywilnoprawnym, skierowane do organu administracji rządowej lub samorządowej, nie wszczyna postępowania administracyjnego na podstawie art. $61 \S 3$ k.p.a.«; postępowanie wszczęte w takiej sprawie podlega umorzeniu" ${ }^{14}$. Skoro - jak stwierdził sąd żądanie takie nie wszczynało postępowania, to $\mathrm{w}$ nieistniejącym postępowaniu nie było podstaw do wydawania jakiejkolwiek decyzji administracyjnej, w tym decyzji o umorzeniu postępowania ${ }^{15}$. W świetle powyższych rozważań nieprzekonujące wydaje się stanowisko L. Żukowskiego, którego zdaniem: „brak określenia w Kpa formy prawnej wszczęcia postępowania i co ważniejsze formy

${ }^{9}$ E. Iserzon, J. Starościak, Kodeks..., s. 144.

${ }^{10}$ Wyrok dostępny na: www.orzeczenia-nsa.pl (10.10.2011).

11 135 NSA w wyroku z 7 września 1989 r. (SA/Ka 441/89, OSP 1991, nr 2, poz. 33) wyraził pogląd, że ,złożenie wniosku przez osobę, która w sprawie nie jest stroną [...] powinno spowodować wydanie odmownej decyzji z przyczyn formalnych, tj. z powodu braku legitymacji procesowej wnioskodawcy"; tak samo wypowiedział się WSA w wyroku z 6 września 2005 r., I SA/Wa 1288/04, Lex, nr 204675.

12 Zob. wyrok NSA z 15 października 1998 r., III SA 955/97, Lex, nr 34944; wyrok WSA z 18 listopada 2004 r. V SA 3379/03, Lex, nr 164691.

${ }^{13}$ Por. W. Chróścielewski, Organ administracji publicznej w postępowaniu administracyjnym, Warszawa 2002, s. 97-98.

${ }^{14}$ A. Wróbel, w: M. Jaśkowska, A. Wróbel, Kodeks postępowania administracyjnego. Komentarz, Kraków 2000, s. 384 oraz zacytowany tam wyrok NSA z 26 lutego 1992 r., I SA 1408/91, „Wokanda” 1992, nr 5, s. 26; „Przegląd Sądowy” 1995, nr 4, s. 92.

15 Jak można domniemywać, pogląd ten pokutował w orzecznictwie sądów administracyjnych od czasów obowiązywania art. 71 r.p.a., nakazującego umorzyć wszczęte postępowanie, jeżeli organ stwierdził brak podstawy prawnej lub faktycznej do merytorycznego załatwienia sprawy. W orzeczeniu z 21 kwietnia 1937 r. Najwyższy Trybunał Administracyjny przedstawił stanowisko, że „Pozostawienie podania bez załatwienia na zasadzie art. 71 Post. Adm. jest decyzją w tym kierunku, że nie ma podstawy prawnej lub faktycznej do merytorycznego załatwienia sprawy, będącej przedmiotem podania, a wobec tego decyzja taka w tym zakresie może być zarówno w toku instancji administracyjnej, jak i w drodze skargi do Trybunału kwestionowana”, „Orzecznictwo Sądów Najwyższych w sprawach Podatkowych i Administracyjnych”, nr 2059, 21 kwietnia 1937 r., l.rej. 3831/34, podaję za: J. Litwin, Postęowanie administracyjne, Łódź 1948, s. 54. 
odmowy takiego wszczęcia rodzi mimo wszystko obowiązek prawny wszczęcia postępowania, by w jego toku wyjaśnić m.in. kwestię legitymacji strony i dać temu wyraz $\mathrm{w}$ formie decyzji merytorycznej lub decyzji o umorzeniu postępowania" 16 .

O tym, jak silna była potrzeba istnienia przepisów uzasadniających wydanie aktu procesowego $\mathrm{w}$ przedmiocie wszczęcia postępowania, świadczy to, że zarówno w doktrynie, jak i judykaturze dopatrywano się podstaw prawnych do wydawania takich postanowień, mimo że przepisy ich nie przewidywały. Przykładem może być stanowisko M. Jaśkowskiej, która lansowała pogląd o wydawaniu (niezaskarżalnych) postanowień w każdym wypadku wszczęcia ostępowania (zarówno z urzędu, jak i na wniosek) w sprawie stwierdzenia nieważności decyzji administracyjnej ${ }^{17}$. Innym przykładem może być zapatrywanie wyrażone w orzecznictwie, w którym podstawy do wydania postanowienia o odmowie wszczęcia postępowania doszukiwano się $\mathrm{w}$ przepisach szczególnych. W wyroku z 21 września 2000 r. (II SA/Łd 1077/97, OSP 2002, $\mathrm{nr} 7-8$, poz. 99) sąd skonstatował: ,W sytuacji, gdy przepis prawa materialnego (art. 30 ustawy z dnia 17 maja 1989 r. - Prawo geodezyjne i kartograficzne) wymaga wydania postanowienia o wszczęciu postępowania rozgraniczeniowego, dopuszczalne jest wydanie przez organ administracji publicznej rozstrzygnięcia o odmowie wszczęcia takiego postępowania $\mathrm{z}$ powodu braku przymiotu strony osoby składającej wniosek". Powyższy błędny pogląd słusznie skrytykowano w piśmiennictwie i zarzucono w następnych orzeczeniach sądów administracyjnych ${ }^{18}$. Powołany tu przepis upoważniał bowiem jedynie do wydawania postanowienia o wszczęciu postępowania rozgraniczeniowego. Wydanie na jego podstawie postanowienia o odmowie wszczęcia postępowania rozgraniczeniowego było działaniem bez podstawy prawnej.

Jednocześnie sądownictwo administracyjne było zgodne co do tego, że Kodeks tylko w dwóch sytuacjach dopuszczał wydawanie decyzji o odmowie wszczęcia postępowania administracyjnego: w wypadku odmowy wszczęcia postępowania w sprawie stwierdzenia nieważności decyzji (art. 157 § 3) oraz w razie odmowy wznowienia postępowania administracyjnego (art. $149 \S 3$ ) $^{19}$. Sytuacje te były jednak wyraźnie sformułowanymi przepisami prawa.

\section{PO WEJŚCIU W ŻYCIE NOWELIZACJI K.P.A.}

\section{Brzmienie nowego przepisu}

11 kwietnia 2011 r. wszedł w życie nowo dodany do k.p.a., na podstawie art. 1 pkt 11 ustawy z 3 grudnia 2010 r. o zmianie ustawy - Kodeks

\footnotetext{
${ }^{16}$ Wyrażone w recenzji wymienionej w przypisie 13 publikacji W. Chróścielewskiego, opublikowanej w ,Studiach Prawno-Ekonomicznych” 2002, nr 66, s. 81.

17 M. Jaśkowska, w: eadem, A. Wróbel, op. cit., s. 927.

18 Zob. wyrok WSA we Wrocławiu z 21 kwietnia 2009 r., III SA/Wr 3/09, Lex, nr 530469; M. Bogusz, glosa do wyroku NSA z 21 września 2000 r., II SA/Łd 1077/97, OSP 2002, nr 7-8, poz. 99.

${ }^{19}$ Wyrok NSA z 7 stycznia 1999 r., IV SA 1736/98, Lex, nr 47339.
} 
postępowania administracyjnego, przepis art. 61a. Przepis ten ma następujące brzmienie:

$\S 1$. Gdy żądanie, o którym mowa w art. 61 , zostało wniesione przez osobę niebędąca stroną lub z innych uzasadnionych przyczyn postępowanie nie może być wszczęte, organ administracji publicznej wydaje postanowienie o odmowie wszczęcia postępowania.

$\S 2$. Na postanowienie, o którym mowa w $§ 1$, służy zażalenie.

Znacznie wcześniej analogiczne rozwiązanie co do formy odmowy wszczęcia postępowania oraz podstaw tej odmowy wprowadzono do Ordynacji podatkowej, która w art. 165a $\S 1$ daje podstawę do wydania postanowienia o odmowie wszczęcia postępowania podatkowego, gdy żądanie jego wszczęcia nie pochodzi od strony bądź z jakichkolwiek innych przyczyn nie może ono być wszczęte. Powyższe rozwiązanie zostało wprowadzone ustawą z 12 września 2002 r. o zmianie ustawy - Ordynacja podatkowa oraz o zmianie niektórych innych ustaw (Dz. U. Nr 169, poz. 1387).

\section{Obowiązek przeprowadzenia w każdym przypadku postępowania o charakterze wstępnym}

Dodanie do k.p.a. cytowanego wyżej przepisu oznacza spełnienie postulatu wysuwanego w nauce prawa i postępowania administracyjnego od dawna, aby $\mathrm{w}$ jurysdykcyjnym postępowaniu administracyjnym, podobnie jak w procedurach sądowych: cywilnej czy karnej, przed przystapieniem do badania meritum sprawy organy administracji prowadziły postępowanie o charakterze wstępnym, którego celem jest ustalenie, czy osoba, która zwróciła się do organu administracji publicznej z żądaniem podjęcia czynności postępowania, a więc która zmierza do doprowadzenia do wszczęcia jurysdykcyjnego postępowania administracyjnego, ma $\mathrm{w}$ tym interes prawny, a więc czy jest legitymowana do tego, aby żądać podjęcia czynności takiego postępowania przez organ administracji publicznej ${ }^{20}$. Użyty w cytowanym przepisie zwrot: „Gdy żądanie, o którym mowa w art. 61, zostało wniesione przez osobę niebędącą strona [...]" oznacza, że od 11 kwietnia 2011 r. organ administracji publicznej, podobnie jak sąd, w pierwszej kolejności jest zobowiązany do przeprowadzenia postępowania mającego na celu ustalenie, czy żądanie wszczęcia postępowania zostało wniesione przez stronę. Chodzi więc o ustalenie na samym wstępie, czy wnoszący żądanie wszczęcia jurysdykcyjnego postępowania ma interes prawny, a więc czy jest legitymowany do występowania w charakterze strony w danym postępowaniu administracyjnym, którego wszczęcie zamierza spowodować. Również na samym wstępie, jeszcze przed przystąpieniem do rozpatrywania meritum sprawy, organ administracji publicznej w każdym wypadku zobowiązany będzie do zbadania, czy w sprawie nie zachodzi inna przeszkoda do wszczęcia postępowania administracyjnego.

${ }^{20} \mathrm{Już}$ w tezach do projektu k.p.a. E. Iserzon proponował wprowadzenie „decyzji o wszczęciu postępowania”. Propozycja ta - co oczywiste - opierała się na założeniu przeprowadzenia postępowania dotyczącego zaistnienia przesłanek wszczęcia postępowania administracyjnego, jako swoistego postępowania wstępnego poprzedzającego merytoryczne rozpoznanie sprawy; podaję za: Z. Janowicz, Ogólne postępowanie administracyjne, Warszawa-Poznań 1978, s. 121. 
Dopiero w wypadku, gdy rezultat omawianego postępowania o charakterze wstępnym okaże się pozytywny dla żądającego wszczęcia postępowania administracyjnego, w tym sensie, że owo postępowanie o charakterze wstępnym wykaże, iż żądający wszczęcia postępowania administracyjnego jest do tego legitymowany, w znaczeniu takim, że ma interes prawny w rozumieniu art. 28 k.p.a. oraz że żądanie, z którym się zawraca do organu administracji publicznej, mieści się w granicach spraw z zakresu administracji publicznej rozstrzyganych w drodze decyzji administracyjnej, zaistnieją warunki do wszczęcia postępowania administracyjnego oraz prowadzenia go w celu wydania decyzji administracyjnej.

\subsection{Zakres stosowania przepisu art. 61a k.p.a.}

W myśl art. 61 k.p.a. postępowanie administracyjne może być wszczęte z urzędu lub na wniosek. O sposobie wszczęcia postępowania w danej sprawie decydują (najczęściej) przepisy prawa materialnego. W niektórych rodzajach spraw postępowanie może być wszczęte tylko z urzędu, w niektórych - tylko na wniosek, a istnieją również takie sprawy, w których przepisy dopuszczają każdą z tych możliwości. Przepis art. 61 a $\$ 1$ dotyczy wszczęcia postępowania zarówno w trybie zwykłym, jak i w trybach nadzwyczajnych i obejmuje wypadki, w których postępowanie można wszcząć na wniosek stron bądź z urzędu - na skutek wniesienia podania przez podmioty na prawach strony - takie jak prokurator oraz Rzecznik Praw Obywatelskich. Ponadto odnosi się on jedynie do postępowania przed organem pierwszej instancji, gdyż postępowanie wstępne, prowadzone przez organ odwoławczy uregulowane jest przepisami art. 134 k.p.a. Poza tym powyższy przepis art.61a k.p.a. nie odnosi się do wszczęcia postępowania w sprawie wpadkowej - na przykład przywrócenia terminu lub zawieszenia postępowania administracyjnego.

$\mathrm{Z}$ art. $61 \mathrm{a} \S 1$ płynie nakaz odmowy wszczęcia postępowania, jeżeli wnioskodawcy nie przysługuje legitymacja procesowa strony. Jednocześnie jednak żądanie pochodzące od takiego podmiotu może stać się impulsem do wszczęcia postępowania z urzędu (o ile oczywiście przepisy w danym przypadku dopuszczają możność wszczęcia postępowania z urzędu). W takim przypadku organ administracji publicznej winien rozważyć podstawy prawne uzasadniające wszczęcie postępowania $\mathrm{z}$ urzędu.

Złożenie przez wnioskodawcę podania w sprawie wszczęcia postępowania skutkuje podjęciem przez organ administracji publicznej czynności procesowych mających na celu ustalenie, czy żądanie pochodzi od strony postępowania. W sprawach, w których z góry wiadomo, kto może występować w charakterze strony (na przykład sprawy zmiany imienia czy nazwiska, których wszczęcia może żądać tylko sam zainteresowany) organ administracji niejako od razu bez konieczności przeprowadzania postępowania wstępnego w tym względzie powinien wydać postanowienie o odmowie wszczęcia postępowania, jeżeli żądanie ewidentnie zostało zgłoszone przez podmiot niemający statusu strony. Natomiast w sytuacjach, gdy status zgłaszającego żądanie nie jest oczywisty 
i wymaga ustalenia (na przykład w sprawach lokalizacyjnych czy budowlanych, w których oprócz inwestora legitymację strony moga niekiedy posiadać także inne podmioty, tak zwani sąsiedzi), organ winien podjąc stosowne czynności procesowe, które pozwola jednoznacznie stwierdzić, czy wnioskodawcy przysługuje legitymacja procesowa strony.

Jedynie wtedy, gdy w chwili składania wniosku nie można jednoznacznie stwierdzić, czy wnoszący podanie posiada przymiot strony w rozumieniu art. 28 k.p.a., wątpliwości należy wyjaśnić w drodze postępowania wyjaśniającego $\mathrm{i}$ - w wypadku ustalenia jego braku - wydać decyzję o umorzeniu postępowania $^{21}$. Taki sam akt procesowy organ administracji publicznej powinien wydać wówczas, gdy w wyniku wadliwej oceny przeprowadzonej w ramach postępowania wstępnego wszczął postępowanie i przeprowadził czynności procesowe, mimo istnienia przyczyn niedopuszczalności.

W kontekście powyższych rozważań warto przypomnieć wyrok NSA z 13 listopada 2007 r., w którym stwierdzono, że: ,[...] przekroczenie granicy skargowości przez wszczęcie postępowania na wniosek jednostki niebędącej stroną w sprawie, stanowi naruszenie prawa, które może kwalifikować się do naruszenia rażącego" ${ }^{22}$. W konsekwencji decyzja kończąca postępowanie (które mogło być wszczęte wyłącznie na wniosek strony), uruchomione na skutek żądania pochodzącego od podmiotu, któremu nie przysługiwał przymiot strony, kwalifikuje się do wyeliminowania z obrotu prawnego w drodze stwierdzenia jej nieważności na podstawie art. $156 \S 1$ pkt 2 k.p.a.

Gdy żądanie strony zawiera braki, wówczas organ obowiązany jest zastosować tryb, o jakim mowa w art. 64 k.p.a. Nieusuwalne braki podania bądź też nieusunięcie przez wzywaną stronę braków podania nie może spowodować wydania postanowienia o odmowie wszczęcia postępowania. W takich okolicznościach organ obowiązany jest pozostawić podanie bez rozpoznania.

Z kolei jeśli jednostka zwróci się do organu administracji z żądaniem wszczęcia postępowania $\mathrm{w}$ sprawie, do której rozpoznania właściwy jest sąd powszechny, w myśl art. $66 \S 3$ - organ administracji zwraca wnoszącemu podanie w drodze postanowienia zaskarżalnego zażaleniem.

\subsection{Przesłanki odmowy wszczęcia postępowania administracyjnego}

\subsection{1. „Gdy żądanie [...] zostało wniesione przez osobę niebędącą stroną”}

W najprostszy sposób wszczęcie postępowania administracyjnego określa się jako początek biegu tego postępowania. Początek ów może być wywołany wyłącznie przez prawem określone podmioty ${ }^{23}$.

$\mathrm{Z}$ jednej strony - w myśl zasady dyspozycyjności (niekiedy nazywanej zasadą rozporządzalności) - postępowanie administracyjne może zostać wszczęte tylko $\mathrm{z}$ inicjatywy (na żądanie) uprawnionego podmiotu, a więc

${ }^{21}$ W. Chróścielewski, Zmiany..., s. 15.

${ }^{22}$ II OSK 1010/07, Lex, nr 423859.

${ }^{23}$ W. Dawidowicz, Postępowanie administracyjne. Zarys wyktadu, Warszawa 1983, s. 131. 
podmiotu posiadającego interes prawny w jego wszczęciu. Oznacza to, że skutecznie z żądaniem wszczęcia postępowania może wystąpić tylko strona (bądź jej pełnomocnik), która ma legitymację procesową w rozumieniu art. 28 k.p.a. ${ }^{24}$ Pomijamy w tym momencie wypadki, gdy przepisy szczególne określaja $\mathrm{w}$ inny sposób legitymację procesową stron postępowania administracyjnego, na przykład w sprawach budowlanych ${ }^{25}$. Z drugiej strony - w myśl zasady oficjalności - w postępowaniu administracyjnym dominującą rolę w zakresie ustalania podmiotowego zakresu sprawy administracyjnej przyznaje się organowi administracji publicznej ${ }^{26}$. Stwierdzenie przez ten organ braku przymiotu strony u osoby wnoszącej żądanie skutkuje koniecznością wydania postanowienia o odmowie wszczęcia postępowania ${ }^{27}$.

Żądanie wszczęcia postępowania może pochodzić również od podmiotów na prawach strony. Przy tym moga oni zasadnie domagać się tego w tych sytuacjach, dla których ustawodawca przewidział możliwość wszczęcia postępowania $\mathrm{w}$ danej kategorii spraw zarówno $\mathrm{z}$ urzędu, jak i na wniosek. Z zasady dyspozycyjności wynika bowiem, że w wypadku gdy postępowanie administracyjne może być wszczęte tylko na wniosek, $\mathrm{z}$ inicjatywą wszczęcia postępowania musi wystąpić strona ( $\mathrm{z}$ drobnym odstępstwem określonym w art. 61 § 2). Jeśli żądanie wszczęcia postępowania zgłosi prokurator lub Rzecznik Praw Obywatelskich (domagający się tego w charakterze podmiotu na prawach strony), a zajdą jednocześnie okoliczności uniemożliwiające jego wszczęcie, organ administracji zobowiązany jest wydać postanowienie $\mathrm{z}$ art. $61 \mathrm{a} \mathrm{k.p.a.}$

Natomiast w sytuacji gdy z wnioskiem o wszczęcie postępowania administracyjnego występuje organizacja społeczna, jako podmiot na prawach strony, art. $61 \mathrm{a} \S 1$ k.p.a. nie ma zastosowania, gdyż wówczas zastosowanie znajduje inny przepis regulujacy jej udział w tym charakterze w postępowaniu administracyjnym, a mianowicie art. $31 \S 2$ k.p.a.

Jeżeli jednak z żądaniem wszczęcia postępowania wystąpi podmiot żądający traktowania go jako organizację społeczną, działającą na prawach strony, której nie będzie można zaliczyć do kategorii wymienionej w art. 5 § 2 pkt 5 Kodeksu (o ile nie będzie to wymagało postępowania wyjaśniającego), organ administracji publicznej powinien wydać postanowienie z art. 61a k.p.a.

\subsection{2. „Z innych uzasadnionych przyczyn postępowanie nie może być wszczęte”}

W jednym z pierwszych komentarzy do analizowanego przepisu A. Wróbel odniósł się krytycznie do tak ujętej przesłanki wydania postanowienia o odmowie wszczęcia postępowania ${ }^{28}$. Wspomniany autor wskazał, że ,oparcie

\footnotetext{
${ }^{24}$ Wyrok WSA z 29 listopada 2007, V SA/Wa 2404/07, Lex, nr 484965.

${ }^{25}$ Por. przepis art. 28 ust. 2 i 40 ust. 3 Prawa budowlanego czy art. 65 ust. 5 zd. 2 ustawy z 27 marca 2003 r. o planowaniu i zagospodarowaniu przestrzennym.

${ }^{26}$ A. Skóra, Wspótuczestnictwo w postepowaniu administracyjnym, Warszawa 2009, s. 256-257.

${ }^{27}$ Jeżeli co najmniej dwie osoby żądają wszczęcia postępowania administracyjnego w danej sprawie, ale tylko jednej z nich przysługuje legitymacja procesowa strony, w stosunku do pozostałych organ powinien wydać postanowienie z art. 61a k.p.a. Postanowienie to wywołuje skutki prawne jedynie wobec jego adresatów.

${ }^{28}$ Opublikowany w: Lex pkt 3.
} 
takiej odmowy na bardzo ogólnej, nieprecyzyjnej przesłance [...] budzi zasadnicze wątpliwości i zastrzeżenia, ponieważ odmowa wszczęcia postępowania administracyjnego [...] powinna być oparta na jasnych i przejrzystych przesłankach procesowo-prawnych, a nie woluntarystyczno-faktycznych, jak w tym przypadku".

Podobnie WSA w Krakowie na gruncie postępowania podatkowego w wyroku z 24 września 2010 r. przedstawił pogląd, że przesłanka „odmowy wszczęcia postępowania $\mathrm{z}$ innych uzasadnionych przyczyn" nie może być interpretowana rozszerzająco ${ }^{29}$.

Jak można przypuszczać, ustawodawca, formułując tę przesłankę wydania postanowienia o odmowie wszczęcia postępowania, miał na myśli takie sytuacje, gdy z żądaniem wszczęcia postępowania zwraca się wprawdzie podmiot, któremu przysługuje legitymacja strony, jednakże jednocześnie zachodzą takie przyczyny, które uniemożliwiaja jego uruchomienie i prowadzenie. Jedną z nich może być res iudicata. W świetle obecnie obowiązującego art. 61a k.p.a. za nie dość dobitną należałoby uznać wypowiedź NSA wyrażoną w postanowieniu z 21 grudnia 2007 r., w którym dopuścił on ewentualność odmowy wszczęcia postępowania sprowadzającą się do tego, iż ,,[...] okoliczność, że sprawa była już przedmiotem rozpoznania [...] może stanowić podstawę odmowy wszczęcia [...] postępowania administracyjnego" ${ }^{30}$.

Innym przykładem okoliczności uzasadniającej odmowę wszczęcia postępowania jest przedawnienie, które na gruncie prawa publicznego funkcjonuje na zasadzie wyjątku. Jak wskazał WSA w Warszawie w wyroku z 14 lutego 2008 r., wniosek właściciela o odszkodowanie za wywłaszczone nieruchomości, złożony 31 grudnia 2005 r., powinien zostać rozpatrzony, skoro przepisy przewidują, że właściciel nieruchomości powinien go złożyć od 1 stycznia 2001 r. do 31 grudnia $2005 \mathrm{r} .{ }^{31}$ Kontynuując tę myśl, należałoby dodać, że wniosek złożony po upływie przewidzianego przez przepisy prawa terminu na dokonanie takiej czynności powinien skutkować wydaniem postanowienia o odmowie wszczęcia postępowania. Takie samo postanowienie organ administracji publicznej powinien wydać $\mathrm{w}$ razie wystąpienia $\mathrm{z}$ żądaniem przywrócenia tego typu terminu przedawnienia, który nie należy do kategorii terminów procesowych (podlegających przywróceniu w trybie art. 58 i 59 Kodeksu).

Ponadto organ administracji powinien wydać postanowienie o odmowie wszczęcia postępowania w sytuacji, gdy postępowanie administracyjne w danej sprawie zostało już wcześniej wszczęte i jest $\mathrm{w}$ toku, zaś z wnioskiem o jego wszczęcie zwraca się jeden z jego współuczestników, którego z momentem jego wszczęcia organ do grona stron tego postępowania nie zaliczył ${ }^{32}$.

${ }^{29}$ I SA/Kr 1070/10, Lex, nr 602883.

${ }^{30}$ II OW 70/07, Lex, nr 460739.

${ }^{31}$ I SA/Wa 1814/07, Lex, nr 459953.

${ }^{32}$ Wszak postępowanie nie może być dwa razy wszczęte w tej samej sprawie. Wydawszy postanowienie o odmowie wszczęcia postępowania, organ administracji publicznej od momentu ujawnienia się w powyższy sposób podmiotu należącego do grona stron danego postępowania zobowiązany jest objąć go czynnościami procesowymi zapewniającymi mu w myśl art. 10 k.p.a. czynny udział w tym postępowaniu. 
Nie można milczeniem pominąć tego, że hipotetycznie możliwa jest również taka sytuacja, iż w pewnym stanie faktycznym jednocześnie wystąpią obie przesłanki wydania postanowienia o odmowie wszczęcia postępowania. W praktyce jednak już wystapienie pierwszej z nich - czyli samo stwierdzenie braku legitymacji procesowej strony - obliguje organ do wydania postanowienia $\mathrm{z}$ art. 61a k.p.a. i jednocześnie zwalnia go $\mathrm{z}$ oceny tego, czy $\mathrm{w}$ danym wypadku nie zaistniała również druga $\mathrm{z}$ przesłanek. Wynika to $\mathrm{z}$ faktu, że art. 61 k.p.a., wyznaczając granice skargowości, wskazuje, że wszczęcie postępowania na wniosek może nastąpić tylko z inicjatywy osoby, która ma legitymację w świetle art. 28 Kodeksu. Oznacza to, że w pierwszej kolejnościorgan zobowiązany jest do zbadania tego, czy wniosek złożył podmiot, który legitymuje się przymiotem strony ${ }^{33}$.

\section{Postanowienie o odmowie wszczęcia postępowania}

Uwagę zwraca okoliczność, że wydanie postanowienia - jako aktu kończącego wspomniane postępowanie o charakterze wstępnym - zostało przewidziane jedynie wówczas, gdy w rezultacie przeprowadzenia tego postępowania okaże się, iż żądający wszczęcia postępowania administracyjnego nie jest do tego legitymowany ze względu na brak po jego stronie interesu prawnego, względnie ze względu na inną przyczynę, stanowiącą przeszkodę do wszczęcia postępowania administracyjnego. W takich i tylko w takich wypadkach ,organ administracji publicznej wydaje postanowienie o odmowie wszczęcia postępowania". Stanowi to wyraz odmowy traktowania przez organ administracji publicznej osoby żądającej wszczęcia postępowania administracyjnego jako strony, a tym samym podmiotu legitymowanego do żądania wszczęcia postępowania administracyjnego. Stanowisko wyrażone w postanowieniu, o którym mowa w art. 61a k.p.a., może być kwestionowane poprzez wniesienie na nie zażalenia (art. 61a $§ 2$ k.p.a.), a w dalszej konsekwencji ze względu na treść art. $3 \S 2$ pkt 2 ustawy z 30 sierpnia 2002 r. - Prawo o postępowaniu przed sądami administracyjnymi (Dz. U. Nr 153, poz. 1270 ze zm.) poprzez uruchomienie drogi sądowoadministracyjnej.

Wskazać można przepisy szczególne, które przewidywały, że odmowa wszczęcia postępowania administracyjnego przybierała postać decyzji, na przykład art. 21 ust. 1 zd. 3 nieobowiązującej już ustawy antymonopolowej stanowił, iż „odmowa wszczęcia postępowania następuje w drodze decyzji”"

Kodeks nie ustanawia konkretnego terminu na wydanie przez organ administracji publicznej postanowienia z art. 61a. Zasada szybkości i prostoty postępowania wyrażona w art. 12 k.p.a. nakazywałaby działać jak najszybciej, tym bardziej że w razie uchylenia postanowienia o odmowie wszczęcia postępowania z powodu jego bezzasadności termin do załatwienia sprawy wszczętej zgłoszonym wcześniej żądaniem biegnie od daty doręczenia tego żądania organowi administracji publicznej.

\footnotetext{
${ }^{33}$ Zob. wyrok NSA z 24 maja 2001 r., IV SA 599/99, Lex, nr 54727.

${ }^{34}$ Ustawa z 24 lutego 1990 r., tekst jedn.: Dz. U. 1999, Nr 52, poz. 547.
} 


\section{Milcząca akceptacja żądania wszczęcia postępowania}

Ostatnie nowelizacje Kodeksu nie wprowadziły żadnych zmian do koncepcji ustawodawcy, w myśl której organy administracji publicznej podejmuja czynności procesowe w toku postępowania administracyjnego bez potwierdzania, że zostały spełnione warunki do rozpoznania sprawy, jeżeli tylko żądanie załatwienia sprawy w formie decyzji do właściwego organu administracji wniosła strona tego postępowania i nie ma innych przeszkód do jego prowadzenia $^{35}$.

Ustawodawca w przepisach Kodeksu nie przewidział wydania żadnego postanowienia ani żadnego innego aktu w razie potwierdzenia - w toku postępowania o charakterze wstępnym - że żądanie, o którym mowa w art. 61 k.p.a., zostało wniesione przez stronę oraz że nie ma żadnej innej przeszkody do wszczęcia postępowania administracyjnego. W rzeczywistości takim domniemanym potwierdzeniem jest niewydanie postanowienia o odmowie wszczęcia postępowania.

Przepisy szczególne mogą przewidywać, że wszczęcie postępowania wymaga od organu administracji wydania stosownego aktu procesowego. W myśl art. 30 ust. 3 i 4 ustawy z 17 maja 1989 r. - Prawo geodezyjne i kartograficzne, wszczęcie postępowania o rozgraniczenie nieruchomości (niezależnie od tego, czy odbywa się to $\mathrm{z}$ urzędu, czy też na wniosek strony) następuje w drodze postanowienia niezaskarżalnego zażaleniem ${ }^{36}$. Warto zauważyć, że w wypadku wszczęcia tego postępowania $\mathrm{z}$ urzędu owo postanowienie odpowiada w swej istocie zawiadomieniu z art. $61 \S 4$ Kodeksu. Natomiast obecnie, w wypadku wszczęcia postępowania rozgraniczeniowego na wniosek, wydawanie tego postanowienia wydaje się zbędne, gdyż - jak to już wyżej wskazano - brak postanowienia o odmowie wszczęcia postępowania z art. 61a k.p.a. jest takim potwierdzeniem.

Brak postanowienia, o którym mowa w art. $61 \mathrm{a} \S 1$ k.p.a., jest równoznaczny ze stwierdzeniem przez organ administracji publicznej, że wnoszący żądanie wszczęcia postępowania administracyjnego ma przymiot strony oraz że nie zachodzi żadna inna przeszkoda we wszczęciu postępowania. Można więc powiedzieć, że jeśli organ administracji publicznej nie zaneguje interesu prawnego i tym samym legitymacji procesowej żądającego wszczęcia postępowania administracyjnego, to można taki brak reakcji traktować jako milcząca akceptację żądania wszczęcia postępowania administracyjnego.

Jeżeli żądanie wszczęcia postępowania złożyła tylko jedna ze stron, to w myśl art. 61 \$ 4 k.p.a. - o wszczęciu postępowania należy zawiadomić pozostałe osoby będące stronami w sprawie.

Rzecz oczywista, milcząca akceptacja żądania wszczęcia postępowania administracyjnego nie jest jeszcze równoznaczna $\mathrm{z}$ akceptacją samego żądania. O akceptacji treści żądania rozstrzygnie się dopiero po merytorycznym rozpatrzeniu sprawy w ramach postępowania administracyjnego i w formie decyzji administracyjnej.

${ }^{35}$ Zob. wyrok NSA z 5 kwietnia 2006 r., II GSK 28/06, Lex, nr 212201.

${ }^{36}$ Tekst jedn.: Dz. U. 2010, Nr 193, poz. 1287 ze zm. 


\section{WSZCZECIE POSTECPOWANIA W TRYBACH NADZWYCZAJNYCH}

\section{Relacja postanowienia wydawanego na podstawie art. 61a do postanowienia wydawanego na podstawie art. $149 \S 3$ k.p.a.}

W myśl ustaleń doktryny postępowanie administracyjne w trybach nadzwyczajnych (w zasadzie) jest wszczynane i prowadzone według tych samych reguł, co postępowanie w trybie zwykłym ${ }^{37}$.

Od 11 kwietnia 2011 r. w wyniku tej samej nowelizacji, która spowodowała dodanie do treści Kodeksu art. 61a, zmienione zostało brzmienie art. $149 \S 3$, który stanowi, że odmowa wznowienia postępowania następuje w drodze postanowienia. Dotychczas przepis ten nakazywał odmawiać wznowienia postępowania w drodze decyzji administracyjnej. Ponadto przy okazji tej samej noweli uchylono $\S 3$ art. 157, który przewidywał, że odmowa wszczęcia postępowania w sprawie stwierdzenia nieważności decyzji następuje w drodze decyzji.

Powyższe zmiany ujednolicają formę, w jakiej następuje odmowa wszczęcia postępowania zarówno w trybie zwykłym, jak i w trybach nadzwyczajnych. Na podstawie art. $149 \S 3$ i $\S 4$ k.p.a. odmowa wznowienia postępowania odbywa się w drodze postanowienia zaskarżalnego zażaleniem. Z kolei uchylenie art. $157 \S 3$ spowodowało, że do wszczęcia postępowania w trybie nadzwyczajnym stwierdzenia nieważności decyzji ma zastosowanie art. 61a. A zatem gdy zaistnienieją podmiotowe lub przedmiotowe przyczyny niedopuszczalności wszczęcia postępowania w sprawie stwierdzenia nieważności decyzji, organ administracji publicznej także zobligowany jest do wydania na podstawie art. 61a Kodeksu postanowienia o odmowie wszczęcia postępowania.

Jednocześnie aktowi odmowy nadano prawidłową postać postanowienia, gdyż - zgodnie z przepisami Kodeksu - postanowienie rozstrzyga kwestie procesowe. Tej formie procesowej odpowiadają względy formalnoprawne, które decydują o wydaniu postanowienia o odmowie wszczęcia postępowania zarówno w trybie zwykłym, jak i w trybach nadzwyczajnych. W tym stanie rzeczy niezrozumiałe jest (oraz niekonsekwentne, zwłaszcza po dodaniu 9 lat temu do Ordynacji art. 165a), utrzymanie przez ustawodawcę w przepisach Ordynacji podatkowej w art. $243 \S 3$ formy decyzji dla odmowy wznowienia postępowania podatkowego.

W ten sposób w ramach Kodeksu ustawodawca osiagnął jednolitość rozwiązań w zakresie odmowy wszczęcia postępowania zarówno w trybie zwykłym, jak i w trybach nadzwyczajnych. Omawiana wyżej jednolitość rozwiązań w zakresie odmowy wszczęcia postępowania administracyjnego nie objęła, niestety, całego systemu procedur przewidujących załatwianie spraw indywidualnych z zakresu administracji publicznej. Nie objęła ona między innymi uregulowania przewidzianego w art. $243 \S 3$ Ordynacji podatkowej, w którym

\footnotetext{
${ }^{37}$ J. Borkowski, w: B. Adamiak, J. Borkowski, Kodeks..., s. 639. Jak wskazuje wspomniany autor, wyjątki od tej reguły dotyczą ustalenia istnienia przesłanek uzasadniających zastosowanie tej instytucji oraz właściwości organu uprawnionego do prowadzenia postępowania w trybie nadzwyczajnym, a także innego zakresu orzekania niż w trybie zwykłym.
} 
w dalszym ciagu utrzymano rozwiązanie przewidujące formę decyzji w przypadku odmowy wznowienia postępowania podatkowego. Zarówno odmowa wszczęcia postępowania $\mathrm{w}$ trybie zwykłym, jak i odmowa wszczęcia postępowania $\mathrm{w}$ sprawie wznowienia postępowania, stwierdzenia nieważności decyzji oraz uchylenia bądź zmiany decyzji na podstawie art. 154 i 155 k.p.a. z przyczyn formalnych - powinny mieć postać postanowienia zaskarżalnego zażaleniem. Dla porządku jedynie odnotować należy, że art. 61a będzie stanowił podstawę do wydania postanowienia o odmowie wszczęcia postępowania w odniesieniu do trybu stwierdzenia nieważności decyzji oraz zmiany bądź uchylenia decyzji na zasadzie art. 154 i 155, natomiast w wypadku wznowienia postępowania podstawę tę formułuje art. 149 § 3 k.p.a. Niezależnie od tego, czy podstawą do wydania postanowienia o odmowie wszczęcia postępowania będzie art. 61a, czy też art. $149 \S 3$ k.p.a., przesłanki ich stosowania sa takie same. Maja charakter formalny i sprowadzają się do niedopuszczalności wszczęcia postępowania z powodów podmiotowych lub przedmiotowych.

Przepis art. $149 \S 3$ k.p.a. to jedyny przepis w grupie unormowań obejmujących postępowanie $\mathrm{w}$ trybach nadzwyczajnych, który wprost stanowi o formie odmowy wszczęcia postępowania. Ponieważ przepisy normujące stwierdzenie nieważności decyzji oraz przepisy normujące uchylenie lub zmianę decyzji w trybie art. 154 i 155 milczą w zakresie formy odmowy wszczęcia postępowania - zastosowanie znajduja przepisy regulujące odmowę wszczęcia postępowania w trybie zwykłym. Wprowadzenie przez ustawodawcę do treści art. $149 \S 3$ postanowienia jako formy odmowy wszczęcia postępowania wynika z konstrukcji przepisu art. 149, który w $\S 1$ przewiduje odmienność w stosunku do pozostałych trybów nadzwyczajnych - w postaci postanowienia o wznowieniu postępowania.

\section{Wszczęcie postępowania na skutek sprzeciwu prokuratora}

Stosownie do art. 182 k.p.a. prokuratorowi służy prawo zwrócenia się do właściwego organu administracji publicznej o wszczęcie postępowania administracyjnego. W starszym i najnowszym nawet piśmiennictwie prezentowany jest pogląd, że żądanie to jest dla organu wiążące ${ }^{38} \mathrm{w}$ tym sensie, iż ,,z dniem doręczenia wniosku organ administracji publicznej podejmuje czynności powodujące wszczęcie postępowania z urzędu" ${ }^{39}$. Powyższy pogląd nie budzi zasadniczych wątpliwości, jednakże obecnie jego argumentacji nie należy poszukiwać ani $\mathrm{w}$ doktrynie, ani $\mathrm{w}$ judykaturze $\mathrm{z}$ czasów Polski Ludowej, lecz należy postrzegać go z innej perspektywy. Wówczas panowały bowiem zupełnie inne uwarunkowania ustrojowo-prawne niż obecnie. Uzasadnienia powyższego stanowiska dostarcza obecnie treść Preambuły do Konstytucji, która stanowi, że jednym z podstawowych praw Rzeczypospolitej Polskiej jest „współdziałanie władz" publicznych. Dostarcza go również wyrażona w art. 2 Konstytucji zasada demokratycznego państwa prawnego, którego organy obowiązane sa do

\footnotetext{
38 J. Borkowski, w: B. Adamiak, J. Borkowski, Kodeks..., s. 673.

${ }^{39}$ A. Wróbel, w: M. Jaśkowska, A. Wróbel, Kodeks..., s. 979.
} 
przestrzegania swych obowiązków, w tym także wobec innych organów władzy publicznej tak, by jedne organy władzy publicznej nie udaremniały ani nie utrudniały możliwości realizacji zadań nałożonych przez ustawodawcę na inne organy ${ }^{40}$. W tym kontekście oraz po dodaniu do treści Kodeksu art. 61a powyższy pogląd - o wiążącym charakterze żądania wszczęcia postępowania przez prokuratora - wypada nieco zrewidować. Ponieważ art. 61a odnosi się do wszczęcia postępowania administracyjnego przed organem pierwszej instancji, powinien mieć on również zastosowanie do wszczęcia postępowania na skutek zgłoszenia stosownego żądania przez prokuratora. Oznacza to, że jeżeli zdaniem organu występuja przeszkody formalne uniemożliwiające merytoryczne rozpatrzenie sprawy (na przykład upływ terminu przedawnienia), organ nie może czuć się bezwzględnie związany żądaniem prokuratora co do wszczęcia postępowania, ale $\mathrm{w}$ takiej sytuacji powinien wydać postanowienie o odmowie wszczęcia postępowania. Te same reguły obowiązuja przy wszczęciu postępowania nadzwyczajnego na skutek wniesienia przez prokuratora sprzeciwu. $\mathrm{W}$ tym wypadku dodatkowym względem, który może przesądzić o wydaniu postanowienia z art. 61a Kodeksu, jest okoliczność, że prokurator wniósł skargę do sądu. W takiej sytuacji - jak stanowi art. 189 k.p.a. - sprzeciw prokuratora uzasadniony przyczynami, dla których wniósł on skargę do WSA, jest niedopuszczalny.

\section{KONKLUZJA}

Konkludując, można powiedzieć, że ustawodawca dokonał kolejnego ważnego kroku na drodze do judycjalizacji jurysdykcyjnego postępowanie administracyjne, a więc upodobnienia go do postępowania sądowego ${ }^{41}$. Sformalizowanie to porządkuje istotną kwestię statusu osób żądających wszczęcia postępowania administracyjnego, zwłaszcza $\mathrm{w}$ tych przypadkach, gdy ich status - jako żądających wszczęcia postępowania administracyjnego, jest wątpliwy, wyraźnie dzieląc postępowanie prowadzone przez organy administracji na dwa etapy. Pierwszy z nich to etap o charakterze wstępnym, w którym postępowanie administracyjne dotyczące meritum jeszcze się nie toczy. Po nim następuje etap drugi - merytorycznego rozpatrywania wniosku strony. Uporządkowanie powyższej kwestii może mieć istotne i w rezultacie pozytywne znaczenie nie tylko dla strony, ale także dla organów administracji publicznej, zwłaszcza w sytuacji, gdy ustawodawca wprowadza rozmaite sankcje za niezałatwienie sprawy administracyjnej w formie decyzji w określonym terminie ${ }^{42}$.

${ }^{40}$ Szerzej problem ten omawiany jest w literaturze niemieckiej; w szczególności zob. H. J. Wolff, O. Bachof, Verwaltungsrecht, t. 3, wyd. 9, München 1974, s. 23 i n.

${ }^{41}$ Szerzej na temat znaczenia gwarancyjnego formalizmu procesowego zob. S. Cieślak, Formalizm postępowania cywilnego, Warszawa 2008, s. 86-88 i 358-359.

${ }^{42}$ Zob. przepis art. 35 ust. 6 Prawa budowlanego, art. 51 ust. 2 ustawy o planowaniu i zagospodarowaniu przestrzenny, art. $11 \mathrm{~h}$ ust. 1 ustawy o szczególnych zasadach przygotowania i realizacji inwestycji w zakresie dróg publicznych. 
Możliwość poddania weryfikacji postanowienia o odmowie wszczęcia postępowania w trybie postępowania sądowoadministracyjnego (jak również w administracyjnych trybach nadzwyczajnych) ma istotne znaczenie w kontekście gwarancji procesowych strony. Stanowi bowiem gwarancję prawną drogi do procesu $^{43}$.

Art. 61a zapewnia jednocześnie odpowiednie gwarancje procesowe jednostce, we wszystkich tych wypadkach, w których ustawodawca w dotychczasowych przepisach przewidział, iż podanie ,nie podlega rozpoznaniu”, ale zarazem nie sprecyzował, na czym ten brak rozpoznania w sensie procesowym powinien polegać. Przykładem może być art. 154 ust. 1 ustawy z 27 sierpnia 2004 r. o świadczeniach opieki zdrowotnej finansowanych ze środków publicznych (tekst jedn.: Dz. U. 2008, Nr 164, poz. 1027 ze zm.), z którego wynika, że żądanie wszczęcia postępowania ,wniesione po terminie nie podlega rozpatrzeniu".

dr Ewa Szewczyk

Docent Państwowej Wyższej Szkoty Zawodowej w Sulechowie

dr hab. Marek Szewczyk

Profesor Uniwersytetu im. Adama Mickiewicza w Poznaniu

\section{REFUSAL TO COMMENCE ADMINISTRATIVE PROCEEDINGS UNDER ARTICLE 61A OF THE CODE OF ADMINISTRATIVE PROCEDURE}

\section{Summary}

This paper concerns the issue described as 'a refusal to commence administrative proceedings', which is of essential importance to the subject being administered, since a refusal to commence administrative proceedings opens up a way for such subject to verify the act using all available legal means.

The authors base their deliberations on the provision of the recent amendment of article 61 of the Code of Administrative Procedure and an addition to it of article 61a which provides that a resolution of refusal to commence administrative proceedings may be passed in two events: (i) when a motion has been submitted by a person who is not a legitimate party to administrative proceedings, and (ii) when, for some other justified reasons, administrative proceedings cannot be commenced.

${ }^{43}$ B. Adamiak, w: eadem, J. Borkowski, Kodeks..., s. 298. 
